\title{
Pengaruh Komunikasi Terhadap Keberhasilan Proyek Pada Hubungan Kerja Antara Kontraktor dan Subkontraktor
}

\author{
Andika Ade Indra Saputra ${ }^{1^{*}}$, Rossana Margaret Kadar Yanti ${ }^{2}$, \\ I Putu Artama Wiguna ${ }^{3}$, Cahyono Bintang Nurcahyo ${ }^{4}$ \\ 1, 2 Program Studi Teknik Sipil, Institut Teknologi Kalimantan \\ ${ }^{3,4}$ Departemen Teknik Sipil, Institut Teknologi Sepuluh Nopember \\ *andika@itk.ac.id
}

\begin{abstract}
Work relations between contractor and subcontractor are implemented to solve the trouble which appears on the project to achieve project success. To achieve that success, effective comunication is required between companies.Therefore, research is needed to analyze the indicators on effective communication and the effect on the success of the inter-company in completing project. This research begins with a review of the literature to get the variables and indicators related to communication and project success. Then do the preparation of the questionnaire as a tool for data collection. Respondent survey used is the manager of the company contractor and subcontractor managers who had been or are involved in working relations. After that, collected data is analyzed by using structural equation modelling (SEM).The results showed that communications gave a positive and significant impact on the success of the project between contractors and subcontractors. Meanwhile, an important indicators of effective communications are communication frequency, two-way communication, clarity of message content, communication honesty, and conflict resolution.
\end{abstract}

Keywords :communication, success of the project, work relations, structural equation modelling

\begin{abstract}
Abstrak
Hubungan kerja antara perusahaan kontraktor dan subkontraktor dilaksanakan untuk mengatasi kesulitan yang muncul di lapangan agar dapat mencapai keberhasilan proyek. Untuk mencapai keberhasilan tersebut diperlukan komunikasi yang efektif antar perusahaan. Oleh karena itulah perlu dilakukan penelitian untuk menganalisis indikator pada komunikasi yang efektif dan pengaruhnya terhadap keberhasilan antar perusahaan tersebut dalam menyelesaikan pekerjaan proyek. Penelitian ini diawali dengan melakukan kajian literatur untuk mendapatkan variabel danindikator terkait komunikasi dan keberhasilan proyek. Kemudian dilakukan penyusunan kuesioner sebagai alat untuk pengumpulan data. Responden pada survey yang digunakan adalah manajer perusahaan kontraktor dan subkontraktor yang pernah atau sedang terlibat dalam hubungan kerja. Selanjutnya data yang terkumpul dilakukan analisis dengan menggunakan structural equation modelling (SEM). Hasil penelitian menunjukkan bahwa komunikasi memberikan pengaruh yang positif dan signifikan terhadap keberhasilan pekerjaan proyek antara perusahaan kontraktor dan subkontraktor. Sedangkan indikator penting pada komunikasi yang efektif adalah frekuensi komunikasi, komunikasi dua arah, kejelasan isi pesan, kejujuran berkomunikasi, dan resolusi konflik
\end{abstract}

Kata kunci :komunikasi, keberhasilan proyek, hubungan kerja, structural equation modelling

\section{Pendahuluan}

Keterbatasan kemampuan dalam penyediaan barang atau jasa oleh suatu perusahaan konstruksi, menuntut untuk dilakukannya kerjasama dengan perusahaan lain yang memiliki kemampuan dalam memenuhi kebutuhan akan barang atau jasa tersebut. Secara umum, Wu et al. [1] menggambarkan alasan mengapa perusahaan konstruksi melakukan kerjasama adalah sebagai berikut. 


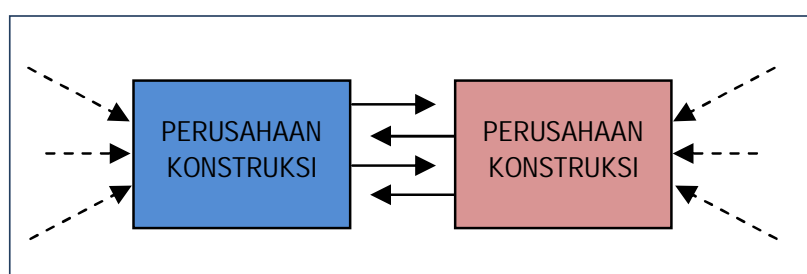

Keterangan:

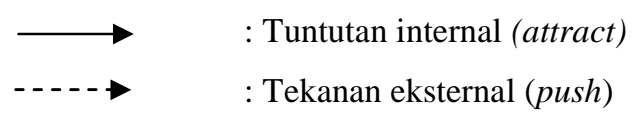

Gambar 1. Alasan Kerjasama Antar Perusahaan Konstruksi

Tekanan eksternal biasanya disebabkan oleh meningkatnya kompleksitas pekerjaan dan teknologi konstruksi serta persaingan pasar yang kuat pada industri konstruksi. Sehingga memaksa suatu perusahaan konstruksi harus menciptakan hubunga kerja dengan perusahaan lain. Sedangkan tuntutan internal pada dasarnya dikarenakan perusahaan tersebut saling membutuhkan dan akan saling menguntungkan. Perusahaan konstruksi yang melakukan kerjasama dengan perusahaan lain akan meningkatkan efisiensi dan mengurangi sumber daya yang dibutuhkan sehingga dapat meningkatkan keuntungan [1].

Hubungan kerja antara kontraktor dan subkontraktor merupakan salah satu bentuk hubungan antara pihak-pihak yang tidak dalam kompetisi langsung, yang digunakan sebagai cara untuk meningkatkan project delivery system dan supply chain dalam pelaksanaan pekerjaan proyek [2]. Kumaraswamy dan Mathews [3] menjelaskan bahwa hubungan kerja antara kontraktor dan subkontraktor dilaksanakan sebagai bentuk untuk saling menguntungkan (win-win solution). Beberapa keuntungan yang bisa didapat ketika melakukan hubungan kerja antara kontraktor dan subkontraktor adalah antara lain meningkatkan hubungan relasi, mengurangi dan membagi resiko, mengurangi biaya, mengurangi sumber daya, dan lain lain[4].Soeharto [5] menambahkan bahwa efisiensi dan produktivitas menjadi alasan perusahaan kontraktor utama menyerahkan sebagian pekerjaan yang menjadi tanggung jawabnya kepada subkontraktor.

Kontraktor sebagai perusahaan pelaksana konstruksi yang dipilih oleh owner berkewajiban untuk melaksanakan dan menyelesaikan pekerjaan sesuai dengan kontrak yang telah disepakati oleh para pihak. Pada proyek konstruksi yang melibatkan subkontraktor di dalamnya, subkontraktor berperan sebagai perusahaan konstruksi yang dikontrak oleh kontraktor utama untuk menyelesaikan sebagian pekerjaan yang menjadi tanggung jawab kontraktor utama [6].

Chan et al. [7] menjelaskan bahwa keberhasilan penyelesaian pekerjaan proyek dapat diukur melalui beberapa kriteria yaitu: waktu, biaya, mutu, kepuasan dari pemilik, kepuasan desainer, kepuasan kontraktor, fungsional, dan variasi proyek. Takim dan Akintoye [8] menambahkan bahwa terdapat 7 indikator yang dapat digunakan untuk mengukur keberhasilan suatu proyek konstruksi yaitu: biaya konstruksi, waktu konstruksi, biaya prediktabilitas, prediktabilitas waktu, cacat, kepuasan pelanggan terhadap produk dan kepuasan pelanggan terhadap jasa.

Pada dasarnya banyak faktor yang dapat mempengaruhi keberhasilan penyelesaian pekerjaan proyek. Lendra dan Andi [9] telah melakukan penelitian yang bertujuan untuk mengetahui tingkat kepercayaan dalam hubungan kerja antara kontraktor dan subkontraktordi Surabaya. Hasil dari penelitian Lendra dan Andi [9] menyebutkan bahwa hubungan kerja antara kontraktor dan subkontraktor di Surabaya memiliki tingkat kepercayaan yang tinggi. Akan tetapi, pada penelitian tersebut juga ditemukan bahwa terdapat perbedaan tingkat kepercayaan yang signifikan jika ditinjau dari faktor pengalaman, serta jenis dan nilai pekerjaan yang dikontrakkan.

Sedangkan pada penelitian Chen dan $\mathrm{Wu}$ [10] komunikasi menempati urutan pertama sebagai faktor yang mempengaruhi keberhasilan proyek. Komunikasi yang efektif dapat membantu dalam memfasilitasi pertukaran ide, visi dan solusi[11]. Kegagalan oleh 
perusahaandalam berkomunikasi secara efektif dapat menyebabkan kesalahpahaman dan kecurigaan, yang pada akhirnya dapat berdampak buruk pada pencapaian hasil serta menyebabkan pemutusan hubungan kerja [12].

Dengan memperhatikan pembahasan di atas, maka perlu untuk dilakukan penelitian tentang pengaruh komunikasi terhadap keberhasilan penyelesaian pekerjaan proyek konstruksi pada hubungan kerja antara kontraktor dan subkontraktor. Pada penelitian sebelumnya, Doloi [13] telah membuat kerangka model dengan menggunakan structural equation modelling (SEM) untuk mengetahui keberhasilan proyek konstruksi di Australia. Dengan mengadopsi penelitian Doloi [13] maka penelitian ini akan menfokuskan untuk mengetahui pengaruh antarakomunikasi terhadap keberhasilan penyelesaian pekerjaan proyek yang pernah atau sedang dikerjakan oleh perusahaan kontraktor dan subkontraktor yang ada di Surabaya.

\section{Metoda Penelitian}

Penelitian ini diawali dengan melakukan kajian literatur dari beberapa jurnal tentang variabel komunikasi dan variabel keberhasilan proyek konstruksi. Dari hasil kajian literatur diperoleh hasil sebagai berikut:

Tabel 1. Variabel Komunikasi.

\section{Indikator}

A1. Frekuensi komunikasi

A2. Komunikasi dua arah

A3. Kejelasan isi pesan

A4. Kejujuran berkomunikasi

A5. Resolusi konflik

A6. Keputusan tanpa tekanan

Tabel 2. Variabel Keberhasilan Proyek.

\section{Indikator}

D1. Tepat Waktu

D2. Tepat Biaya

D3. Tepat Mutu

Dari hasil kajian literatur dan pola kerangka pemikiran yang telah dilakukan, selanjutnya dilakukan hipotesis model penelitian dari keberhasilan pekerjaan proyek.

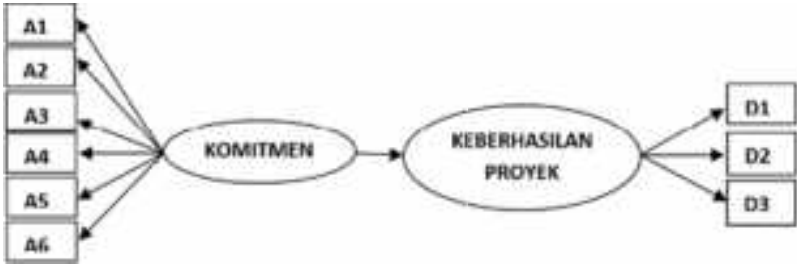

Gambar 2. Hipotesis Model Penelitian

Berdasarkan pada hipotesis model penelitian gambar 2, maka hipotesis yang diajukan dalam penelitian ini adalah:

$H$ : Komunikasi berpengaruh terhadap keberhasilan penyelesaian proyek.

Hasil kajian literatur selanjutnya digunakan untuk menyusun pertanyaan pada kuesioner yang digunakan sebagai instrumen penelitian. Kuesioner disusun untuk memperoleh jawaban persepsi dari responden mengenai variabel dan indikator dengan menggunakan skala lickert 15. Responden dalam penelitian ini adalah manajer proyek atau jabatan setara yang pernah atau sedang terlibat dalam penyelesaian pekerjaan proyek antara kontraktor dan subkontraktor yang ada di Surabaya. Penyebaran kuesioner dilakukan dengan metode snow ball pada perusahaan PT. Gorip Nusa Guna, PT. Harapan Indah, dan PT. Pembangunan Perumahan. Dari 128 kuesioner yang telah disebar, kuesioner yang kembali sebanyak 91 kuesioner dan hanya 90 kuesioner yang memenuhi syarat untuk dapat diolah.

Kuesioner yang terkumpul berasal dari 39 perusahaan pelaksana konstruksi, dengan rincian sebanyak 24 perusahaan kontraktor umum dan 15 perusahaan kontraktor spesialis yang terlibat dalam pekerjaan proyek sebagai subkontraktor. Dari hasil survey kuesioner yang telah dilaksanakan diketahui bahwa responden yang bekerja di perusahaan kontraktor umum sebanyak $73 \%$ dan perusahaan kontraktor spesialis sebanyak 27\%. Hal ini menunjukkan bahwa dari kesuluruhan perusahaan kontraktor di Surabaya yang terlibat dalam pelaksanaan pekerjaan proyek, perusahaan kontraktor umum lebih banyak dari pada kontraktor spesialis. 
Berikut adalah profil responden dan perusahaan yang terlibat dalam penelitian ini.

Tabel 3. Profil Responden Penelitian.

\begin{tabular}{clcc}
\hline No & Tempat Kerja & Jumlah & Persentase (\%) \\
\hline $\mathbf{1}$ & Kontraktor & 66 & 73 \\
$\mathbf{2}$ & Subkontraktor & 24 & 27 \\
\hline & Jumlah & 90 & 100 \\
\hline
\end{tabular}

Selanjutnya dari data yang terkumpul melalui survey kuesioner dilakukan analisis data structural equation modelling (SEM). Analisis full modelSEM digunakan untuk menguji kesesuaian model yang diajukan dalam hipotesis. Sebelum membentuk full model SEM, terlebih dahulu dilakukan pengujian terhadap faktor-faktor yang membentuk masing-masing variabel. Pengujian dilakukan dengan menggunakan uji kesesuaian (goodness of fit) melalui model confirmatory factor analysis (CFA).

\section{Hasil Penelitian}

Langkah pertama sebelum pengolahan data dengan menggunakan SEM, perlu dilakukan uji kebaikan pengukuran yang meliputi reliabilitas dan validitas terhadap kuesioner yang telah disebarkan ke 90 responden yang memenuhi kriteria sebagai sampel.

Oleh karena jumlah sampel yang terkumpul kurang dari syarat minimum $5 \times \mathrm{N}$ indikator dan hasil uji normalitas menunjukkan terdapat data yang terdistribusi tidak normal, maka analisis SEM dilakukan dengan melakukan bootstrap terlebih dahulu. Dengan menggunakan program bantu LISREL 8.70, bootstrap dilakukan secara default program dengan memilih 50 data dan dilakukan pengulangan sebanyak 100 kali. Selanjutnya dilakukan analsisis terhadap model SEM yang digunakan untuk mendapatkan dan menguji kesesuain model yang diajukan dalam hipotesis.Sebelum membentuk full model SEM, terlebih dahulu akan dilakukan pengujian terhadap faktor-faktor yang membentuk masingmasing variabel. Pengujian dilakukan dengan menggunakan uji kesesuaian (Goodness of Fit) melalui model Confirmatory Factor Analysis
(CFA). Selanjutnya kesimpulan atas kesesuaian model yang dibangun dapat dilihat dari hasil output Goodness of Fit yang diperoleh.

\subsection{Uji Validitas dan Reliabilitas}

Suatu konstruk atau variabel dikatakan reliable jika memberikan nilai $\alpha$ cronbach $>0,7$. Hasil pengujian reliabilitas mununjukkan bahwa pada sampling responden $\mathrm{n}=90$ menghasilkan nilai $\alpha$ cronbach $>0,7$ sehingga semua dikatakan reliabel. Berikut adalah perhitungan koefisien yang telah diolah dan ditabelkan sebagai berikut:

Tabel 4. Profil Responden Penelitian

\begin{tabular}{lccc}
\hline \multicolumn{1}{c}{ Variabel } & N & a cronbach & Keterangan \\
\hline Komunikasi & 6 & 0.733 & Reliabel \\
Keberhasilan & 3 & 0.785 & Reliabel
\end{tabular}

Uji validitas digunakan untuk mengukur valid atau tidaknya suatu kuisioner. Uji validitas dilakukan dengan membandingkan nilai $r$ hitung dengan $r$ tabel. Jika $r$ hitung lebih besar dari $r$ tabel dan nilai $r$ positif, maka pernyataan tersebut dikatakan valid. Jumlah sampel $(\mathrm{N})=$ 90 dan taraf signifikan sebesar 5\%, maka diperoleh nilai $\mathrm{r}$ tabel $=0.207$. Berikut adalah penjelasan uji validitas berdasarkan masingmasing variabel.

Tabel 5. Uji Validitas Variabel Komunikasi

\begin{tabular}{llcc} 
No & \multicolumn{1}{c}{ Indikator } & $\mathbf{r}_{\text {hitung }}$ & Keterangan \\
A1 & Frekuensi Komunikasi & 0.525 & Valid \\
A2 & Komunikasi Dua Arah & 0.532 & Valid \\
A3 & Kejelasan Isi Pesan & 0.699 & Valid \\
A4 & Kejujuran Berkomunikasi & 0.577 & Valid \\
A5 & Resolusi Konflik & 0.408 & Valid \\
A6 & Keputusan Tanpa Tekanan & 0.169 & Tidak Valid \\
& $\mathrm{r}_{\text {tabel }}(90: 5 \%)=0.207$ & &
\end{tabular}

Oleh karena terdapat indikator yang tidak valid dalam satu variabel maka perlu dilakukan uji validitas ulang pada variabel yang sama dengan menghilangkan indikator yang sebelumnya dikatakan tidak valid. Berikut pada tabel 6 . adalah modifikasi perhitungan uji validitas pada 
variabel komunikasi dengan menghilangkan indikator keputusan tanpa tekanan (A6).

Tabel 6. Uji Validitas Variabel Komunikasi

\begin{tabular}{llcc}
\hline No & \multicolumn{1}{c}{ Indikator } & $\mathbf{r}_{\text {hitung }}$ & Keterangan \\
\hline A1 & Frekuensi Komunikasi & 0.609 & Valid \\
A2 & Komunikasi Dua Arah & 0.634 & Valid \\
A3 & Kejelasan Isi Pesan & 0.693 & Valid \\
A4 & Kejujuran & 0.590 & Valid \\
& Berkomunikasi & & \\
A5 & Resolusi Konflik & 0.347 & Valid
\end{tabular}

$r_{\text {tabel }}(90: 5 \%)=0.207$

Berdasarkan tabel 6. setelah dilakukan modifikasi dengan menghilangkan indikator keputusan tanpa tekanan (A6) di atas dapat diketahui bahwa pada indikator frekuensi komunikasi (A1), komunikasi dua arah (A2), kejelasan isi pesan (A3), kejujuran berkomunikasi (A4), dan resolusi konflik (A5) memiliki nilai $r$ hitung $>r$ tabel, maka kelima indikator pada variabel komunikasi di atas dapat dikatakan valid dan dapat digunakan untuk analisis selanjutnya.

Sedangkan hasil perhitungan uji validitas terhadap indikator pada variabel keberhasilan proyek dapat dijelaskan pada tabel 7 . berikut:

Tabel 7. Uji Validitas Variabel Komunikasi

\begin{tabular}{llcc}
\hline No & Indikator & $\mathbf{r}_{\text {hitung }}$ & Keterangan \\
\hline D1 & Tepat Waktu & 0.537 & Valid \\
D2 & Tepat Biaya & 0.815 & Valid \\
D3 & Tepat Mutu & 0.554 & Valid \\
\hline
\end{tabular}

$\mathrm{r}$ tabel $(90: 5 \%)=0.207$

Berdasarkan tabel 7. dapat diketahui bahwa pada indikatortepat waktu (D1), tepat biaya (D2) dan tepat mutu (D3) memiliki nilai $r$ hitung $>r$ tabelmaka ketiga indikator pada variabel komunikasi di atas dapat dikatakan valid dan dapat digunakan untuk analisis selanjutnya.

\subsection{Confirmatory Factor Analysis(CFA)}

Analisis faktor konfirmatori ini merupakan tahap pengukuran terhadap indikator-indikator yang membentuk variabel laten dalam model penelitian. Tujuan dari analisis faktor konfirmatori adalah untuk menguji unidimensional dari dimensi-dimensi pembentuk masing-masing variabel laten. Analisis konfirmatori dilakukan pada masingmasing variabel eksogen dan variabel endogen. Pada model penelitian ini hanya terdapat satu variabel eksogen yaitu komunikasi dan variabel endogen, yaitu keberhasilan penyelesaian pekerjaan proyek. Berikut adalah hasil analisis faktor konfirmatori pada variabel komunikasi yang tersaji pada gambar 3 .

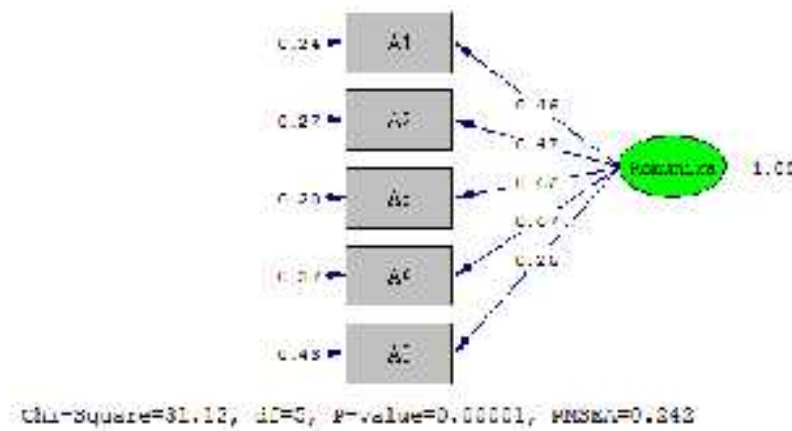

Gambar 3.CFA Komunikasi (Estimate)

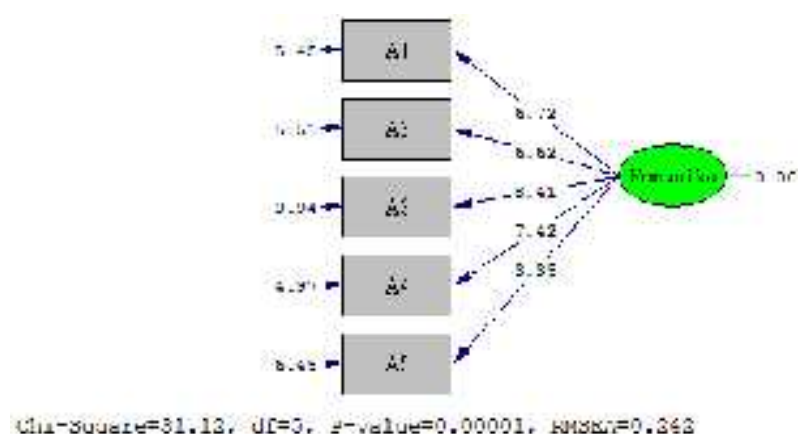

Gambar 4.CFA Komunikasi (T-value)

Tabel 8. Uji Kesesuaian Model Komunikasi

\begin{tabular}{cccc}
$\begin{array}{c}\text { KriteriaGoodness } \\
\text { of Fit }\end{array}$ & $\begin{array}{c}\text { Cut-off } \\
\text { Value }\end{array}$ & $\begin{array}{c}\text { Hasil } \\
\text { Model }\end{array}$ & Kesimpulan \\
\hline $\boldsymbol{\chi}_{i}^{2}$ Statistics & kecil & 31,12 & Kurang baik \\
Probability & $\geq 0,05$ & 0,00 & Kurang baik \\
GFI & $\geq 0,90$ & 0,88 & Kurang baik
\end{tabular}




$\begin{array}{cccc}\text { AGFI } & \geq 0,90 & 0,63 & \text { Kurang baik } \\ \text { RMSEA } & <0,08 & 0,24 & \text { Kurang baik }\end{array}$

Hasil analisis faktor konfirmatori awal (estimate)pada variabel komunikasi menunjukkan bahwa semua indikator yang digunakan memiliki nilai $\mathrm{t}_{\text {hitung }}(\mathrm{t}$ value $)>\mathrm{t}$ tabel $\left(\mathrm{t}_{(\alpha, \mathrm{df})}\right)$ sesuai yang ditunjukkan pada gambar 4 . Sehingga semua indikator yang digunakan berpengaruh signifkan dapat digunakan untuk mengukur variabel komunikasi.

Akan tetapi pada saat dilakukan uji kesesuaian model yang disajikan padatabel 8 , pada model komunikasi menunjukkan hasil yang kurang baik. Oleh karena itu perlu dilakukan modifikasi untuk memperbaiki model fit. Berikut adalah hasil modifikasi variabel komunikasi.

Tabel 9. Estimasi Parameter Variabel Komunikasi

\begin{tabular}{lcccc} 
Hubungan & $\begin{array}{c}\text { Loading } \\
\text { Factor }\end{array}$ & $\begin{array}{c}\text { Estimas } \\
\mathbf{i}\end{array}$ & $\begin{array}{c}\mathbf{t}_{\text {hitun }} \\
\mathbf{g}\end{array}$ & $\begin{array}{c}\text { Error } \\
\text { Variance }\end{array}$ \\
\hline $\begin{array}{l}\text { Komunikasi } \\
\rightarrow \text { A1 }\end{array}$ & $\lambda_{1}$ & 0,55 & 7,97 & 0,16 \\
$\begin{array}{c}\text { Komunikasi } \\
\rightarrow \text { A2 }\end{array}$ & $\lambda_{2}$ & $\mathbf{0 , 5 8}$ & $\mathbf{8 , 1 4}$ & $\mathbf{0 , 1 6}$ \\
$\begin{array}{c}\text { Komunikasi } \\
\rightarrow \text { A3 }\end{array}$ & $\lambda_{3}$ & 0,46 & 5,74 & 0,37 \\
$\begin{array}{c}\text { Komunikasi } \\
\rightarrow \text { A4 }\end{array}$ & $\lambda_{4}$ & 0,46 & 4,70 & 0,60 \\
$\begin{array}{c}\text { Komunikasi } \\
\rightarrow \text { A5 }\end{array}$ & $\lambda_{5}$ & 0,27 & 3,40 & 0,42 \\
\hline dimana $t_{0,05 ; 4}=2,776$ & & &
\end{tabular}

Berdasarkan tabel 9. di atas dapat diketahui pula bahwa indikator yang paling berpengaruh pada variabel komunikasi adalah indikator komunikasi dua arah (A2) dengan nilai estimasi loading factor $(\lambda) 58 \%$. Hal ini menunjukkan bahwa komunikasi dua arah sangat penting dalam suatu hubungan kerja yang melibatkan dua pihak atau lebih yang memiliki peran dan tanggung jawab yang berbeda. Komunikasi akan lebih terjalin dengan baik apabila ada komunikasi dua arah dari pihak yang terlibat dalam hubungan kerja. Secara bergantian dengan mekanisme yang ada, pihak-pihak yang terlibat dalam suatu hubungan kerja saling memberikan informasi atau menyampaikan pesan, dan memberikan respon dari pesan atau informasi yang diterima. Dengan demikian, pesan atau informasi yang disampaikan akan dapat diketahui apakah pihak lain mengerti dan paham maksud dari isi pesan yang telah disampaikan.

Berbeda dengan variabel eksogen yaitu komunikasi, variabel endogen dengan tiga indikator yang menyertai menunjukkan hasil analisis faktor konfirmatori yang sangat baik tanpa perlu dilakukan modifikasi. Hasil dari analisis CFA pada variabel ini menunjukkan nilai derajat kebebasan $(\mathrm{df})=0$. Nilai chi-square yang dihasilkan dari analisis ini pun sangat kecil, bahkan bernilai 0,00. Begitu juga dengan probability yang hasilkan dari analisis CFA menunjukkan nilai $\mathrm{p}$ value $=1$.

\subsection{Analisis SEM Pada Hubungan Kerja Kontraktor dan Subkontraktor}

Setelah dilakukan modifikasi pada model SEM secara utuh, hasil uji kesesuaian belum menunjukkan hasil yang fit. Akan tetapi nilai yang dihasilkan setelah dilakukan modifikasi menunjukkan angka yang lebih baik mendekati kriteria fit pada uji kesesuaian. Nilai chi square yang awalnya 412,36 setelah dilakukan modifikasi menjadi 278,87. Nilai GFI dan AGFI yang awalnya 0,68 dan 0,60 setelah dilakukan modifikasi nilai GFI menjadi 0,76 dan nilai AGFI $=0,69$. Begitu juga dengan nilai RSMEA yang setelah dilakukan modifikasi memiliki nilai yang mendekati kriteria fit yaitu 0,081 . Secara lengkap hasil uji kesesuaian setelah dilakukan modifikasi tersaji pada tabel 10 . berikut ini.

Tabel 10. Estimasi Parameter Variabel Laten SEM

\begin{tabular}{ccccc} 
Hubungan & $\boldsymbol{\gamma}$ & Est & T-value & Keterangan \\
\hline$\underset{\text { Komunikasi }}{\rightarrow}$ & $\gamma_{10}$ & 0,45 & 2,87 & Signifikan
\end{tabular}

Keberhasilan dimana $\mathrm{t}_{0,05 ; 176}=1,976$

Parameter estimasi untuk pengujian pengaruh komunikasi terhadap keberhasilan penyelesaian pekerjaan proyek menunjukkan nilai $\mathrm{t}_{\text {hitung }}=2,87$. Nilai tersebut memenuhi syarat penerimaan hipotesis yaitu $t_{\text {hitung }}=2,87$ $>\mathrm{t}_{\text {tabel }}=1,976$. Dengan demikian dapat disimpulkan bahwa hipotesis yang menyatakan 
bahwa komunikasi berpengaruh terhadap keberhasilan penyelesaian pekerjaan proyek dapat diterima. Hal ini menunjukkan bahwa terdapat pengaruh positif dan signifikan antara komunikasi dan keberhasilan penyelesaian pekerjaan proyek dalam suatu hubungan kerja antara kontraktor dan subkontraktor di Surabaya. Semakin tinggi komunikasi yang terbentuk maka semakin tinggi pula keberhasilan penyelesaian pekerjaan proyek yang dapat dicapai pada hubungan kerja.

\subsection{Pembahasan}

Dari hasil uji hipotesis yang telah dilakukan membuktikan bahwa komunikasi memiliki pengaruh positif dan signifikan terhadap keberhasilan penyelesaian pekerjaan proyek pada hubungan kerja antara kontraktor dan subkontraktor di Surabaya. Arah positif yang dihasilkan dari analisis menunjukkan bahwa semakin tinggi komunikasi yang tercipta antara perusahaan kontraktor dan perusahaan subkontraktor maka semakin tinggi pula tingkat keberhasilan yang dapat dicapai.

Berdasarkan hasil analisis jalur dari variabel komunikasi ke variabel keberhasilan juga menunjukkan bahwa komunikasi memiliki pengaruh langsung yang kuat terhadap keberhasilan penyelesaian pekerjaan proyek. Kondisi ini ditunjukkan dari hasil analisis, di mana nilai koefisien path $=0,45(>0,30)$. Hasil penelitian ini menguatkan penelitian sebelumnya yang telah dilakukan oleh Cowan et al. [17] yang menyebutkan bahwa keberhasilan suatu hubungan kerja dapat ditunjukkan dengan tingkat kualitas komunikasi yang tinggi. Dengan terciptanya komunikasi yang baik dari masingmasing pihak yang terlibat dalam hubungan kerja, maka permasalahan yang mungkin muncul selama pelaksanaan pekerjaan proyek juga dapat ditangani dengan sebaik-baiknya.

Hasil penelitian ini juga menunjukkan bahwa dalam hal komunikasi pada suatu hubungan kerja yang melibatkan lebih dari satu pihak, komunikasi dua arah menjadi hal terpenting yang harus menjadi perhatian demi terwujudnya kualitas komunikasi yang baik. Dari hasil analisis, komunikasi dua arah memiliki nilai loading factor ( $\lambda \mathrm{A} 2)$ yang tertinggi yaitu $58 \%$. Hal ini juga erat kaitannya dengan seberapa seringnya komunikasi yang dapat terjalin selama proses pelaksanaan pekerjaan proyek. Hasil analisis menunjukkan bahwa indikator frekuensi komunikasi (A1) juga memiliki peran yang tertinggi kedua $(\lambda \mathrm{A} 1=55 \%)$ dalam mempengaruhi variabel komunikasi. Seringnya komunikasi dua arah yang terjalin antar masing-masing pihak juga akan berbanding lurus dengan dapat terciptanya komunikasi yang efektif dalam suatu hubungan kerja yang melibatkan lebih dari satu pihak yang berkepentingan.

Di dalam prakteknya, komunikasi secara umum termasuk selama pelaksanaan proyek biasanya dibedakan menjadi 3 yaitu:push, pull, dan dua arah. Komunikasi bersifat push, apabila satu pihak mengirimkan informasi ke banyak pihak lain sebagai penerima informasi, tanpa ada umpan balik dari penerima. Sedangkan komunikasi yang bersifat pull apabila penerima pesan mencari dan mendapatkan informasi dari pengirim pesan, tanpa ada umpan balik dari pengirim pesan. Komunikasi push dan pull dapat dikatakan sebagai komunikasi satu arah. Jenis komunikasi ini sangat tidak efektif apabila diterapkan dalam proyek yang melibatkan lebih dari satu pihak berkepentingan. Pekerjaan proyek dapat berjalan lebih lancar apabila masing-masing pihak yang terlibat dapat menciptakan komunikasi dua arah yang baik. Beberapa jenis komunikasi dua arah yang dapat digunakan selama pelaksanaan pekerjaan proyek adalah tatap muka langsung, teleconference, dan telepon. Sehingga informasi dan respon yang dibutuhkan demi keberhasilan pekerjaan proyek dapat sampai dengan cepat.

Hasil ini juga mendukung penelitian sebelumnya oleh Crowley et al. [18] yang mengatakan bahwa komunikasi yang efektif mempunyai dua tujuan utama, yaitu: penerima pesan mendapatkan pemahaman penuh tentang makna pesan yang diberikan dan pengirim pesan juga mendapatkan tanggapan dari penerima pesan. Begitu juga dengan Mohr dan Spekman [19] yang telah terlebih dahulu menyebutkan bahwa komunikasi dua arah 
menjadi penting untuk menjamin terjadinya tukar informasi atau umpan balik dari kedua belah pihak yang sedang terlibat kerjasama.

\section{Kesimpulan}

Berdasarkan hasil penelitian dan pembahasan maka dapat disimpulkan bahwa komunikasi berpengaruh signifikan terhadap keberhasilan penyelesaian pekerjaan proyek. Dari beberapa indikator yang ada pada variabel komunikasi, hanya indikator frekuensi komunikasi, komunikasi dua arah, kejelasan isi pesan, kejujuran berkomunikasi, dan resolusi konflik yang dapat digunakan pada penelitian ini.

Dari kelima indikator, komunikasi dua arah menjadi fokus utama yang perlu diperhatikan dan ditingkatkan dalam suatu hubungan kerja antara kontraktor dan subkontraktor. Sehingga keberhasilan penyelesaian proyek baik biaya, mutu, ataupun waktu dapat tercapai secara tepat.

\section{Saran}

Berdasarkan keterbatasan penelitian ini, maka disarankan untuk dilakukan penelitian lanjutan yang lebih mendetail dengan membedakan masing-masing grade perusahaan kontraktor dan membedakan spesialisasi bidang pekerjaan perusahaan subkontraktor. Sehingga dapat diperoleh informasi yang lebih mendalam terkait perbedaan yang muncul dari masingmasing jenis perusahaan.

\section{Daftar Pustaka}

[1] S. Wu, D. Greenwood, and G. Steel, "Exploring the Atributes of Collaborative Working in Construction Industry", Northumbria Built and Virtual Environtment Working Paper Series, vol. 1, no. 2, hal. 135-147, 2008.

[2] A. B. Ngowi, "The role of trustworthiness in the formation and governence of construction alliances", Building and Environment, vol. 42, pp. 1828-1835, 2007.

[3] M. M. Kumaraswamy, and J. D. Matthews, "Improved Subcontractor Selection Employing Partnering Principles", J. Management in
Engineering, vol. 16, no. 3, pp. 47-57, 2000.

[4] C. Black, A. Akintoye, and E. Fitgerald, "An analysis of success factors and benefits of partnering in construction", Int. J. Project Management, vol. 18, pp. 423-434, 2000.

[5] I. Soeharto, Manajemen Proyek (Dari Konseptual Sampai Operasional), Jakarta : Erlangga, 2001.

[6] L. Y. Lian, H. R. Muniandy and L. T. Hua, "Review of Subcontracting Practice in Construction Industry", Int. J. Engineering and Technology, vol. 4, no. 4, pp. 442-445, 2012.

[7] A. P. C. Chan, D. W. M. Chan, Y. H. Chiang, B. S. Tang, E. H. W. Chan, and K. S. K. Ho, "Exploring Crtitical Success Factors for Partnering in Construction Projects", J. Construction Eng. and Management, vol. 130, no. 2, pp. 188-198, 2004.

[8] R. Takim, and A. Akintoye, "Performance Indicators For Successful Construction Project Performance", 18th Annual ARCOM Conference, vol. 2, pp. 545-555, 2002.

[9] Lendra dan Andi, "Tingkat Kepercayaan Dalam Hubungan Kemitraan Antara Kontraktor dan Subkontraktor di Surabaya", Civil Eng. Dimension, vol. 8, no. 2, pp. 55-62, 2006.

[10] T. T. Chen and F. Y. Wu, "Explore Critical Factors for Partnering in the Taiwanese Construction Industry", Proceedings of the 2010 Int. Conf. on Engineering, Project and Production Management, pp. 234-242, 2010.

[11] E. W. L. Cheng, H. Li, and P. E. D. Love, "Establisment of Critical Success Factors for Construction Partnering", $J$. Management in Engineering, vol. 16, no. 2, hal. 84-92, 2000.

[12] Y. L. Doz, "The evolution of cooperation in strategic alliances: initial conditions or learning processes?", Strategic Management Journal, vol. 17, pp. 55-83, 1996.

[13] H. Doloi, "Relational partnerships: the importance of communication, trust and confidence and joint risk management in achieving project success", Construction 
Management and Economics, vol. 27, pp. 1099-1109, 2009

[14] F. D. Lazar, "Project Partnering: Improving the Likelihood of WinWin Outcomes", J. Management In Engineering, vol. 16, no. 2, hal. 71-83, 2000.

[15] S. O. Cheung, T. S. T. Ng, S. K. Wong, and H. C. H. Seun, "Behavioral aspects in construction partnering", Int. J. Project Management, vol. 21, pp.. 333343, 2003.

[16] P. S. P. Wong, and S. O. Cheung, "Trust in construction partnering: views from parties of the partnering dance", Int. J. Project Management, vol. 22, pp. 437446, 2004.

[17] C. Cowan, C. Gray, and E. Larson, "Project partnering", Project Management Journal, vol. 22, no. 4, pp. 5-12, 1992.

[18] L. G. Crowley and A. Karim, "Conceptual Model of Partnering", $J$. Management in Engineering, vol. 11, no. 5, pp. 33-39, 1995

[19] J. Mohr and R. Spekman, "Characteristic of partnering success: Partnering attributes, communication behaviour, and conflict resolution techniques", J. Strategic Management, vol. 15, no. 2, pp. 135-152, 1994. 